\title{
Regioselective synthesis of highly substituted enol esters from ketoketene dimer $\beta$-lactones
}

\author{
Eric C. Salo, Kyle R. Dayak, Jacob Huxford, Pei-Hsun Wei, \\ Nicholas J. Peraino and Nessan J. Kerrigan* \\ Department of Chemistry, Oakland University, 2200 N. Squirrel Rd, \\ Rochester, MI 48309-4477, USA \\ E-mail: kerrigan@oakland.edu
}

DOI: http://dx.doi.org/10.3998/ark.5550190.p008.443

\begin{abstract}
A method for the regioselective synthesis of highly substituted enol esters from ketoketene dimers $\beta$-lactones is described. Methylphenylketene dimer was subjected to a sequential one-pot reaction sequence involving ring-opening with an organolithium to give an enolate intermediate, followed by enolate acylation with an acyl chloride to give a highly substituted enol ester as the final product. Complete regioselectivity for $O$-acylation of the enolate was observed in all cases. Yields of up to $70 \%$ were obtained for the one-pot conversion of ketoketene dimers to highly substituted enol esters.
\end{abstract}

Keywords: Ketoketene dimer, ketene dimer, enol ester, enolate, $\beta$-lactone, organolithium

\section{Introduction}

Enol esters are useful compounds as they can be used as electron-rich ene components in a variety of cycloadditions (including [2 +2$],[3+2]$, and Diels-Alder reactions), and also act as substrates for cyclopropanation reactions, and asymmetric hydrogenations. ${ }^{1-3} \mathrm{~A}$ popular synthetic route to enol esters involves acylation of enolates. However, a lack of regioselectivity between $O$-acylation and $C$-acylation can be encountered as a problem. ${ }^{4,5}$ Another issue that can plague synthetic routes to enol esters is a lack of stereoselectivity in enol formation. ${ }^{6,7}$ Consequently, both direct and indirect methods that provide access to enol esters in a regioselective and stereoselective fashion are desirable. ${ }^{8-11}$

Among the best stereoselective approaches to highly substituted enol esters are the tandem carbometallation-oxygenation of terminal alkynes developed by Ready and co-workers. ${ }^{10}$ However tetrasubstituted enol esters cannot be prepared using this method. Other notable 
methods include those of Yanada, which utilizes internal alkynes as starting materials and provides access to tetrasubstituted enol esters via a sequential cohalogenation and palladiumcatalyzed cross-coupling. ${ }^{11}$ Although the method is highly stereoselective, it favors formation of the $E$-isomer in most cases where the acetylene terminus is alkyl-substituted. If the Z-isomer is desired, it cannot be achieved from alkyl-substituted acetylenes.

A few years ago, both our group and that of Ye reported systems for the dimerization of ketoketenes (disubstituted ketenes). ${ }^{12-14}$ In 2010, our group reported a versatile chiral phosphine catalytic system (Josiphos) which provided a general method for the asymmetric homodimerization of ketoketenes (Scheme 1). ${ }^{15}$

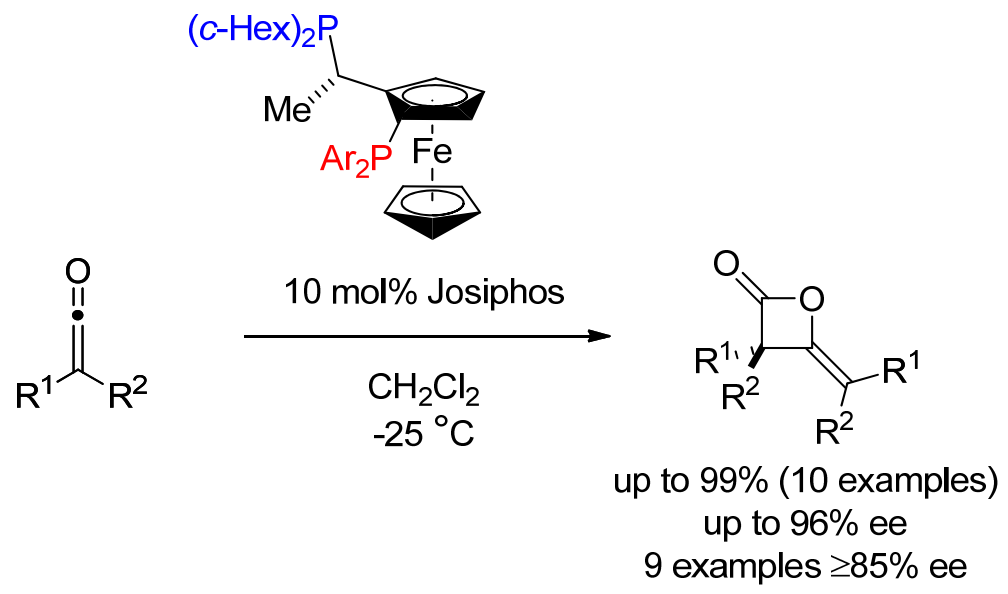

Scheme 1. Phosphine-catalyzed asymmetric homodimerization of ketenes.

We also recently showed that 1,3-diketones could be accessed in a diastereoselective fashion from ketoketene dimers through reaction with excess organolithium followed by reaction quenching with a proton source. ${ }^{16}$ A surprising aspect of the latter reaction was that only single addition of the nucleophile to the lactone ester occurred, and hence a new route to 1,3-diketones became possible. We were intrigued by the possibility that this reaction could be extended to enolate trapping with electrophiles other than proton sources to give other useful products, such as enol esters. We anticipated that a ketene homodimerization reaction, followed by a sequential ring-opening/electrophile trapping procedure, would provide an efficient and regioselective route to highly substituted enol ester products (Scheme 2). Moreover the resulting enol ester products would provide a way by which ketoketene dimers could be utilized in the synthesis of natural products and drug molecules. We anticipated that successful oxidative cleavage of the enol ester olefin would facilitate its use in synthetic activities. ${ }^{17}$ In this paper we describe our studies on the development of a regioselective route to highly substituted enol esters from ketoketene dimer $\beta$ lactones. 


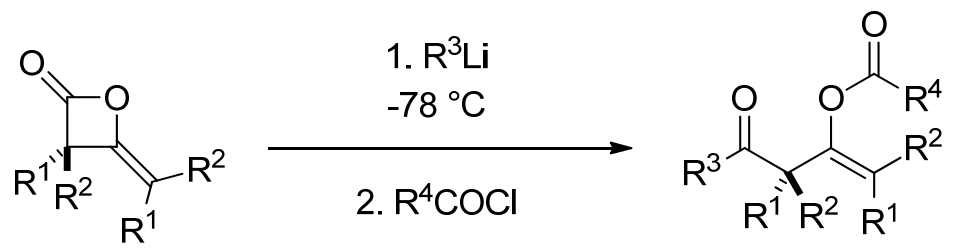

Scheme 2. Proposed ring-opening of ketoketene dimers to give enol esters.

\section{Results and Discussion}

We began our investigations with a focus on the ring-opening of methylphenylketene dimer, as we felt that the resulting enol ester product, bearing an $\alpha$-quaternary stereogenic center with a methyl substituent, would prove useful in synthetic activities, particularly with the synthesis of LY426965 in mind (Scheme 3). ${ }^{18}$
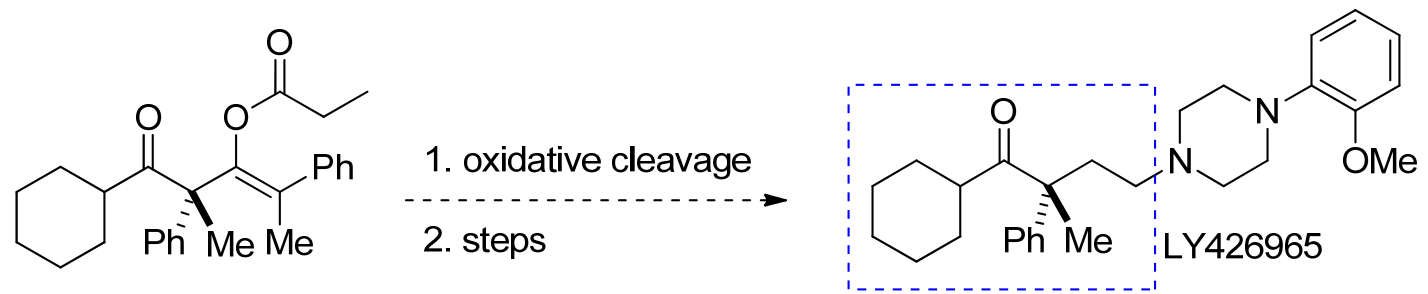

Scheme 3. Potential application of enol esters to the synthesis of LY426965.

$n$-BuLi was chosen as a representative nucleophilic organometallic for reaction optimization because we had previously achieved success with it in the formation of 1,3-diketones. Propionyl chloride was chosen for study as the electrophilic trapping agent not just due to its high reactivity, but also because of its volatility which would enable easier isolation and purification of the enol ester product.

When 2 equiv of our initially favored ring-opening nucleophile $n$-BuLi was used, access to the desired product with promising conversion (40\%) was facilitated (Table 1, entry 1). We then proceeded to evaluate a variety of reactant stoichiometries (entry 1-3). The use of less than 2 equiv of the primary alkyllithium nucleophile was found to have a beneficial effect on conversion/yield to enol ester, presumably due to reduction of side reactions involving excess organolithium (entry 3 vs entry 1). Optimal reaction conditions involved the use of 1 equiv of the $n$-BuLi solution (2.5 M in hexane), 2 equiv of propionyl chloride, with the ketoketene dimer $\beta$ lactone being initially at a concentration of $0.1 \mathrm{M}$ in $\mathrm{THF}$ at $-78{ }^{\circ} \mathrm{C}$. Another important consideration (not mentioned in Table 1) was the finding that allowing the reaction to warm to room temperature for a minimum of 30 minutes after organolithium addition at $-78{ }^{\circ} \mathrm{C}$ facilitated optimal conversion. 
Table 1. Optimization of the synthesis of enol ester $\mathbf{2 a}$ from ketoketene dimer $\mathbf{1 a}^{a}$

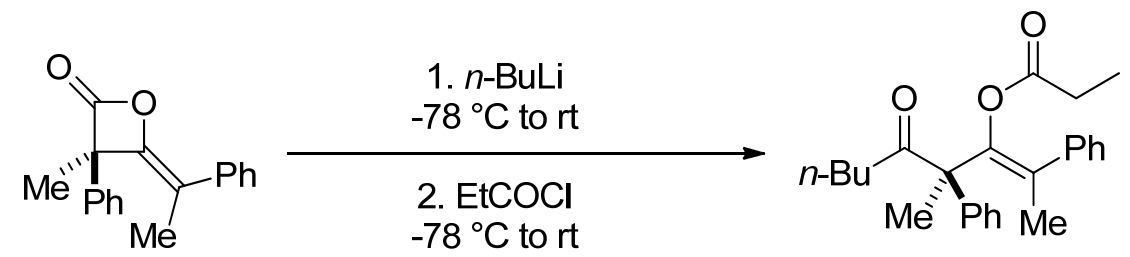

\begin{tabular}{cccc}
\hline Entry & Equiv of $n$-BuLi & Equiv of acyl chloride & Conv. $^{a}$ \\
\hline 1 & 2 & 4 & 40 \\
2 & 1.2 & 2 & 44 \\
3 & 1 & 2 & 78 \\
\hline
\end{tabular}

${ }^{\mathrm{a}}$ Conversion (Conv) determined by GC-MS analysis of crudes.

Next we evaluated the optimized conditions for reaction of a secondary alkyllithium, chexyllithium, with methylphenylketene dimer. Interestingly in this case, a greater number of equivalents of alkyllithium was found to be beneficial to reaction efficacy (Table 2, entry 3 ). This may be due to the more sterically hindered nature of the secondary alkyllithium reagent (Table 2).

Table 2. Optimization of the synthesis of enol ester $\mathbf{2} \mathbf{b}$ from ketoketene dimer $\mathbf{1 a}^{a}$

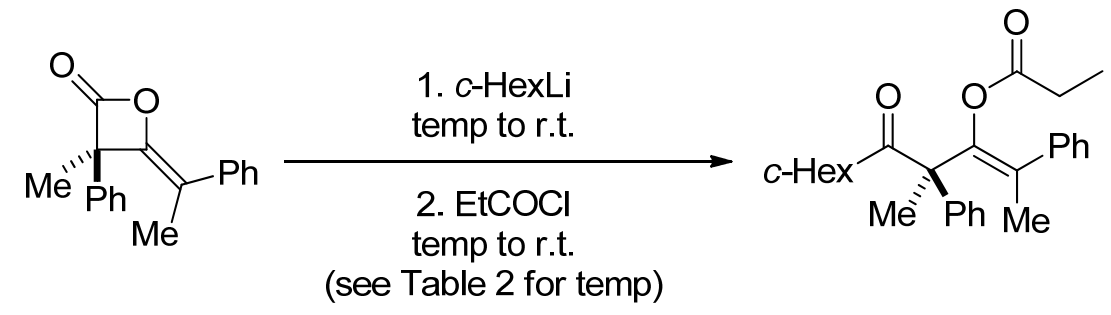

\begin{tabular}{ccccc}
\hline Entry & Temp. $\left({ }^{\circ} \mathrm{C}\right)$ & Equiv of $c$-HexLi & $\begin{array}{c}\text { Equiv of acyl } \\
\text { chloride }\end{array}$ & Conv $^{a}$ \\
\hline 1 & 0 & 1 & 2 & 54 \\
2 & -78 & 1 & 2 & 62 \\
3 & -78 & 2 & 4 & 80 \\
\hline
\end{tabular}

${ }^{a}$ Conversion (Conv) determined by GC-MS analysis of crudes. 
We then investigated different examples of the optimized reaction system (conditions from Table 1 entry 3 in most cases), with respect to the structure of the organolithium, acyl achloride and ketoketene dimer involved (Table 3 ).

Table 3. Examples of the synthesis of enol esters $\mathbf{2 a - 2 h}$ from 1a-1c
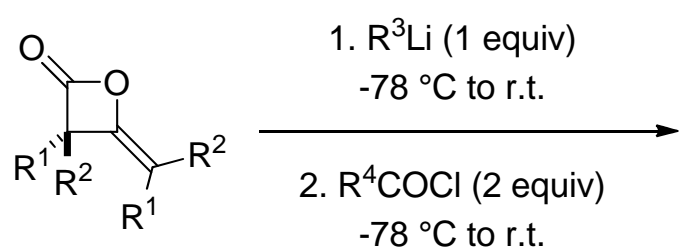

1a: $R^{1}=M e, R^{2}=P h$

$-78^{\circ} \mathrm{C}$ to r.t.

1b: $\mathrm{R}^{1}=\mathrm{Me}, \mathrm{R}^{2}=4-\mathrm{MeC}_{6} \mathrm{H}_{4}$

1c: $R^{1}=E t, R^{2}=P h$

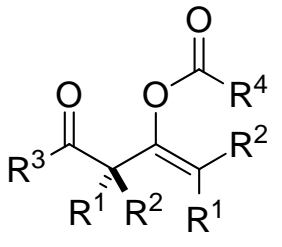

2a-h

\begin{tabular}{ccccccc}
\hline Entry & $\mathrm{R}^{1}$ & $\mathrm{R}^{2}$ & $\mathrm{R}^{3}$ & $\mathrm{R}^{4}$ & Yield $^{a}(\mathrm{Conv})$ & Product $^{2}$ \\
\hline 1 & $\mathrm{Me}$ & $\mathrm{Ph}$ & $n-\mathrm{Bu}$ & $\mathrm{Et}$ & 70 & $\mathbf{2 a}$ \\
$2^{b}$ & $\mathrm{Me}$ & $\mathrm{Ph}$ & $n-\mathrm{Bu}$ & $\mathrm{Et}$ & 61 & $(+)-\mathbf{2 a}$ \\
$3^{\mathrm{c}}$ & $\mathrm{Me}$ & $\mathrm{Ph}$ & $c-\mathrm{Hex}$ & $\mathrm{Et}$ & 66 & $\mathbf{2 b}$ \\
4 & $\mathrm{Me}$ & $\mathrm{Ph}$ & $t-\mathrm{Bu}$ & $\mathrm{Et}$ & trace & $\mathbf{2 c}$ \\
5 & $\mathrm{Me}$ & $\mathrm{Ph}$ & $\mathrm{Ph}$ & $\mathrm{Et}$ & 0 & $\mathbf{2 d}$ \\
6 & $\mathrm{Me}$ & $\mathrm{Ph}$ & $n-\mathrm{Bu}$ & $\mathrm{Me}$ & $37(87)$ & $\mathbf{2 e}$ \\
7 & $\mathrm{Me}$ & $\mathrm{Ph}$ & $n-\mathrm{Bu}$ & $\mathrm{Ph}$ & $<10(88)$ & $\mathbf{2 f}$ \\
8 & $\mathrm{Me}$ & $4-\mathrm{MePh}$ & $n-\mathrm{Bu}$ & $\mathrm{Et}$ & 41 & $\mathbf{2 g}$ \\
9 & $\mathrm{Et}$ & $\mathrm{Ph}$ & $n-\mathrm{Bu}$ & $\mathrm{Et}$ & $<10$ & $\mathbf{2 h}$ \\
\hline
\end{tabular}

${ }^{a}$ Yields are isolated yields. ${ }^{b}(-)-1$ a was used as ketoketene dimer. Entries 1-7 (except entry 2) involved the use of $( \pm)$-1a. In entry $8,( \pm)$-1b was used. In entry $9,( \pm)$-1c was used. ${ }^{c} 2$ equiv. of $c$-HexLi and 4 equiv. of acyl chloride used.

In many cases, a good yield of the desired enol ester could be achieved, with best results observed when a primary or secondary alkyllithium was used as the ring-opening nucleophile (entries 1-3, Table 3). When a tertiary alkyllithium was used, no enol ester was formed, a result which contrasts with our earlier findings in 1,3-diketone formation, where $t$-BuLi proved an effective ring-opening agent (entry 4). Aromatic organolithiums also proved ineffective (entry 5), presumably due to retro-aldol reaction after double addition of the phenyllithium nucleophile to the ketoketene dimer. ${ }^{16}$ Trapping the intermediate resulting from nucleophilic attack of the organolithium on ketoketene dimers proved most effective when propionyl chloride was used as 
the acyl chloride. The use of other more reactive acyl chlorides (acetyl chloride and benzoyl chloride) led to lower isolated yields of the corresponding enol esters, which is likely to be due to increased side reactions involving these acyl chlorides (entries 6 and 7). As regards the ketoketene dimer component of the reaction, methylarylketene dimers gave best results, while ethylphenylketene dimer was less effective due to increased steric hindrance about the lactone carbonyl (entries 1 and $8 v s$ entry 9). In all cases only one stereoisomer of the enol ester was formed as determined by GC-MS and NMR analysis of the crude product. The major isomer of the enol ester 2 a was determined to be the Z-isomer on the basis of NOESY experiments, which demonstrated an NOE between the two Me groups of the enol ester (Figure 1). The major isomer of all other enol esters was assigned to be the $Z$-isomer by analogy. Evidently, no loss of stereochemical purity (no olefin isomerization) occurred on going from ketoketene dimer starting material $(Z: E \geq 95: 5)$ to enol ester product as determined by GC-MS and ${ }^{1} \mathrm{H}$ NMR analysis of the crude product in each case.

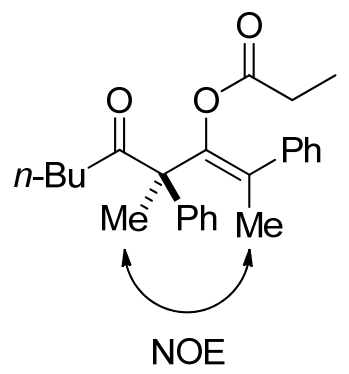

Figure 1. NOE observed, supporting assignment of Z-geometry to enol ester 2a.

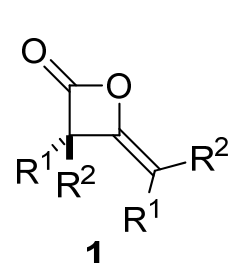

1
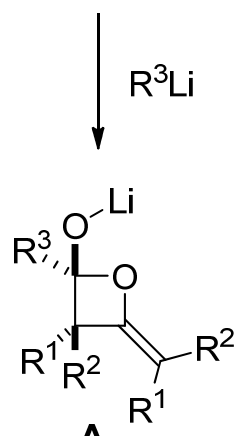

A
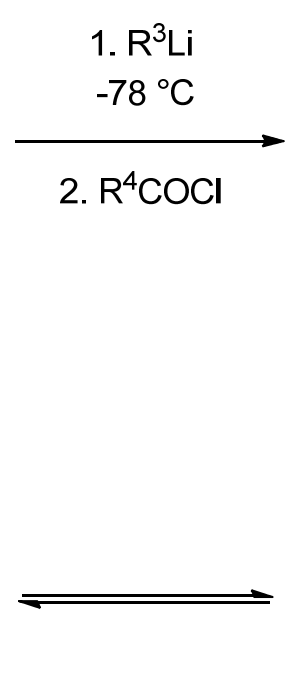

$\mathrm{R}^{3}$<smiles>[R]C([R])=C1O[AlH]OC([R])C1[R]</smiles>

B

Scheme 4. Possible mechanism for the formation of enol ester 2. 
The mechanism of the reaction is presumed to involve initial nucleophilic addition of the organolithium to the lactone carbonyl of $\mathbf{1}$ (Scheme 4). A lithium lactol $\mathbf{A}$ in equilibrium with lithium enolate $\mathbf{B}$ is expected to result. Double addition of the nucleophile is minimized if the lithium lactol intermediate dominates at equilibirum. Acylation of lithium enolate intermediate $\mathbf{B}$ occurs more readily than that of lithium lactol $\mathbf{A}$, because of the superior nucleophility of the enolate. Regioselective $O$-acylation results due to greater steric hindrance at the $\mathrm{C}$ of the enolate rather than at the $\mathrm{O}$ of the enolate, and moreover due to a preference for the hard electrophile (acyl chloride) to react with the harder nucleophilic site of the lithium enolate intermediate B (the oxygen). ${ }^{19,4,5}$

\section{Conclusions}

In summary, we have developed a method that provides access to tetrasubstituted enol esters from ketoketene dimers with excellent regioselectivity and retention of olefin stereochemistry.

\section{Experimental Section}

General. THF was dried using a sodium/benzophenone still under nitrogen prior to use. ${ }^{20}$ Dry pentane was obtained by passing through activated alumina columns on a solvent purification system. Most organolithium reagents were purchased from Aldrich Chemical Co and used as received. Cyclohexyllithium solution (ca. 1.0 M in pentane) was prepared through modification of a procedure by Esmay and Kamienski. ${ }^{21,22}$ All reactions were carried out in flame-dried glassware under a nitrogen atmosphere using standard inert atmosphere techniques unless otherwise stated. Neutral silica (Iatrobeads from Bioscan, 6RS-8060, $60 \mu \mathrm{M}$ particle size) and TLC plates (Sorbent Technologies, UV254, $250 \mu \mathrm{M}$ ) were used as received. Ketoketene homodimers 1a-1c were prepared using procedures previously described by our group. ${ }^{12,15}$ NMR spectra were recorded on a Bruker DPX Avance 200 spectrometer $\left(200 \mathrm{MHz}\right.$ for ${ }^{1} \mathrm{H}$ and $50 \mathrm{MHz}$ for ${ }^{13} \mathrm{C}$ ) and on a Bruker Biospin AG 400 spectrometer (400 $\mathrm{MHz}$ for ${ }^{1} \mathrm{H}$ and $100 \mathrm{MHz}$ for $\left.{ }^{13} \mathrm{C}\right)$. NMR chemical shifts were reported relative to TMS $(0 \mathrm{ppm})$ for ${ }^{1} \mathrm{H}$ and to $\mathrm{CDCl}_{3}$ (77.23 ppm) for ${ }^{13} \mathrm{C}$ spectra. IR spectra were recorded on a Bruker Alpha Platinum ATR spectrometer. Optical rotations were measured on a Rudolph DigiPol 781 TDV automatic polarimeter.

Low resolution mass spectra were recorded on a GC-MS Hewlett Packard HP 6890 GC instrument with a 5973 mass selective detector, and using a Restek Rtx-CL Pesticides2 GC column (30 m, $0.25 \mathrm{~mm}$ ID). High resolution mass spectra were obtained from the College of Sciences Major Instrumentation Cluster at Old Dominion University and on an Agilent Technologies 6520 Accurate Mass Q-TOF LC-MS instrument at Oakland University. 
General synthetic procedure, exemplified by (Z)-4-methyl-5-oxo-2,4-diphenylnon-2-en-3ylpropionate (2a). $( \pm)$-1a (50 mg, $0.19 \mathrm{mmol})$ was dissolved in THF (1.5 mL), and $n$-BuLi (2.5 $\mathrm{M}$ in hexane, $0.08 \mathrm{~mL}, 0.19 \mathrm{mmol}$ ) was added dropwise over $2 \mathrm{~min}$ at $-78^{\circ} \mathrm{C}$. The reaction was stirred for $5 \mathrm{~min}$ at $-78{ }^{\circ} \mathrm{C}$ and warmed up to room temperature for $30 \mathrm{~min}$. The reaction mixture was again cooled to $-78{ }^{\circ} \mathrm{C}$ before being quenched by adding propionyl chloride $(0.03$ $\mathrm{mL}, 0.38 \mathrm{mmol})$. The reaction was taken out of the cooling bath and warmed up to room temperature over $1 \mathrm{~h}$. Brine $(8 \mathrm{~mL})$ and $\mathrm{CH}_{2} \mathrm{Cl}_{2}(5 \mathrm{~mL})$ were added, and the layers were separated. The aqueous layer was extracted with $\mathrm{CH}_{2} \mathrm{Cl}_{2}(2 \times 5 \mathrm{~mL})$, and the combined organics were dried over anhydrous $\mathrm{Na}_{2} \mathrm{SO}_{4}$. The solvent was removed under reduced pressure. In some

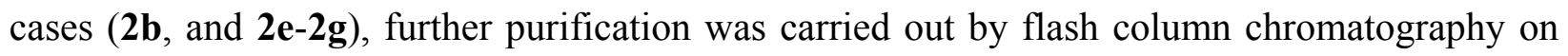
neutral silica (iatrobeads), eluting with a gradient solvent system (from hexane to $2 \%$ EtOAc/hexane).

2a. Colorless oil, yield 70\%, $50 \mathrm{mg}, \mathrm{dr}>95: 5$ as determined by ${ }^{1} \mathrm{H}$ NMR and GC-MS analysis; IR ( $v_{\max }, \mathrm{cm}^{-1}$, thin film): 1715,$\left.1756 ;{ }^{1} \mathrm{H} \mathrm{NMR} \mathrm{(400} \mathrm{MHz,} \mathrm{CDCl}_{3}, \mathrm{TMS}\right): \delta_{\mathrm{H}} 0.66(\mathrm{t}, J 7.5 \mathrm{~Hz}$, $3 \mathrm{H}), 0.79(\mathrm{t}, J 7.3 \mathrm{~Hz}, 3 \mathrm{H}), 1.21-1.23(\mathrm{~m}, 2 \mathrm{H}), 1.37-1.50(\mathrm{~m}, 2 \mathrm{H}), 1.57(\mathrm{~s}, 3 \mathrm{H}), 1.70(\mathrm{~s}, 3 \mathrm{H})$, $1.78-1.83(\mathrm{~m}, 2 \mathrm{H}), 2.54-2.58(\mathrm{~m}, 2 \mathrm{H}), 7.14-7.49(\mathrm{~m}, 10 \mathrm{H}) ;{ }^{13} \mathrm{C} \mathrm{NMR}\left(100 \mathrm{MHz}, \mathrm{CDCl}_{3}\right): \delta_{\mathrm{C}} 8.8$, $14.1,21.1,22.6,23.6,27.0,27.3,39.2,61.6,127.1,127.1,127.8,128.3,128.3,128.5,129.9$, 141.2, 141.6, 143.7, 172.7, 210.3; MS (EI $70 \mathrm{eV}): \mathrm{m} / z$ 322, 293, 237, 220, 205, 190; (M + Na) ${ }^{+}$ HRMS: $m / z$ Calcd for $\left(\mathrm{C}_{25} \mathrm{H}_{30} \mathrm{O}_{3} \mathrm{Na}\right)^{+}: 401.2087$; found: 401.2084 .

(S,Z)-4-Methyl-5-oxo-2,4-diphenylnon-2-en-3-ylpropionate $((+)-2 a)$. Colorless oil, yield 61\%, $27 \mathrm{mg}, \mathrm{dr}>95: 5$ as determined by ${ }^{1} \mathrm{H}$ NMR and GC-MS analysis; $[\alpha]_{\mathrm{D}}=29.4\left(\mathrm{c}=0.22, \mathrm{CHCl}_{3}\right)$; IR ( $v_{\max }, \mathrm{cm}^{-1}$, thin film): $1715,1756 \mathrm{~cm}^{-1} ;{ }^{1} \mathrm{H}$ NMR $\left(400 \mathrm{MHz}, \mathrm{CDCl}_{3}, \mathrm{TMS}\right): \delta_{\mathrm{H}} 0.66(\mathrm{t}, J 7.5$ $\mathrm{Hz}, 3 \mathrm{H}), 0.79$ (t, J 7.3 Hz, 3H), 1.21-1.23 (m, 2H), 1.37-1.50 (m, 2H), $1.57(\mathrm{~s}, 3 \mathrm{H}), 1.70(\mathrm{~s}, 3 \mathrm{H})$, $1.78-1.83(\mathrm{~m}, 2 \mathrm{H}), 2.54-2.58(\mathrm{~m}, 2 \mathrm{H}), 7.14-7.49(\mathrm{~m}, 10 \mathrm{H}),{ }^{13} \mathrm{C} \mathrm{NMR}\left(100 \mathrm{MHz}, \mathrm{CDCl}_{3}\right): \delta_{\mathrm{C}} 8.8$, 14.1, 21.1, 22.6, 23.6, 27.0, 27.3, 39.2, 61.6, 127.1, 127.1, 127.8, 128.3, 128.3, 128.5, 129.9, 141.2, 141.6, 143.7, 172.7, 210.3; MS (EI $70 \mathrm{eV}): \mathrm{m} / z$ 322, 293, 237, 220, 205, 190; $(\mathrm{M}+\mathrm{Na})^{+}$ HRMS m/z calcd for $\left(\mathrm{C}_{25} \mathrm{H}_{30} \mathrm{O}_{3} \mathrm{Na}\right)^{+}: 401.2087$; found: 401.2084 .

(Z)-5-Cyclohexyl-4-methyl-5-oxo-2,4-diphenylpent-2-en-3-ylpropionate (2b). Colorless oil, yield 66\%, $29 \mathrm{mg}$, dr $>95: 5$ as determined by ${ }^{1} \mathrm{H}$ NMR and GC-MS analysis; IR ( $v_{\max }, \mathrm{cm}^{-1}$, thin film): 1264, 1707, $2930 \mathrm{~cm}^{-1} ;{ }^{1} \mathrm{H}$ NMR (400 MHz, $\left.\mathrm{CDCl}_{3}, \mathrm{TMS}\right): \delta_{\mathrm{H}} 0.65$ (t, J 7.3 Hz, 3H), 1.10$1.90(\mathrm{~m}, 12 \mathrm{H}), 1.48(\mathrm{~s}, 3 \mathrm{H}), 1.73(\mathrm{~s}, 3 \mathrm{H}), 2.85(\mathrm{~m}, 1 \mathrm{H}), 7.13-7.54(\mathrm{~m}, 10 \mathrm{H}) ;{ }^{13} \mathrm{C}$ NMR $(100$ $\left.\mathrm{MHz}, \mathrm{CDCl}_{3}\right): \delta_{\mathrm{C}} 8.8,21.2,23.4,25.9,26.0,27.3,30.7,31.3,48.0,61.9,127.0,127.0,127.8$, 128.3, 128.7, 130.2, 140.4, 141.6, 143.0, 172.7, 210.2; MS (EI $70 \mathrm{eV}): \mathrm{m} / \mathrm{z} 293,237,220,205$; $(\mathrm{M}+\mathrm{H})^{+} \mathrm{HRMS} m / z$ Calcd for $\left(\mathrm{C}_{27} \mathrm{H}_{33} \mathrm{O}_{3}\right)^{+}:$405.2424; found: 405.2432.

(Z)-4-Methyl-5-oxo-2,4-diphenylnon-2-en-3-ylacetate (2e). Colorless oil, yield 37\%, $22 \mathrm{mg}$, dr $>95: 5$ as determined by GC-MS analysis; Selected characterization data: IR $\left(v_{\max }, \mathrm{cm}^{-1}\right.$, thin film): 1713, $1755 \mathrm{~cm}^{-1} ;{ }^{1} \mathrm{H} \mathrm{NMR}\left(200 \mathrm{MHz}, \mathrm{CDCl}_{3}, \mathrm{TMS}\right): \delta_{\mathrm{H}} 0.79$ (t, J $\left.7.4 \mathrm{~Hz}, 3 \mathrm{H}\right), 1.13-1.27$ $(\mathrm{m}, 2 \mathrm{H}), 1.35-1.50(\mathrm{~m}, 2 \mathrm{H}), 1.55(\mathrm{~s}, 3 \mathrm{H}), 1.57(\mathrm{~s}, 3 \mathrm{H}), 1.71(\mathrm{~s}, 3 \mathrm{H}), 2.51-2.57(\mathrm{~m}, 2 \mathrm{H}), 7.14-7.50$ $(\mathrm{m}, 10 \mathrm{H}) ;{ }^{13} \mathrm{C}$ NMR $\left(100 \mathrm{MHz}, \mathrm{CDCl}_{3}\right): \delta_{\mathrm{C}} 14.1,20.4,21.0,22.6,23.6,27.0,39.3,61.6,127.2$, $127.7,128.3,128.3,128.4,128.5,129.9,141.1,141.6,143.8,169.1,208.3 ;$ MS (EI $70 \mathrm{eV}): \mathrm{m} / \mathrm{z}$ 
338, 322, 279, 237, 220; $(\mathrm{M}+\mathrm{H})^{+}$HRMS m/z Calcd for $\left(\mathrm{C}_{24} \mathrm{H}_{29} \mathrm{O}_{3}\right)^{+}$: 365.2111; found: 365.2115 .

(Z)-4-Methyl-5-oxo-2,4-diphenylnon-2-en-3-ylbenzoate (2f). Colorless oil, yield 6\%, $4 \mathrm{mg}, \mathrm{dr}$ $>95: 5$ as determined by ${ }^{1} \mathrm{H}$ NMR and GC-MS analysis; IR ( $v_{\max }, \mathrm{cm}^{-1}$, thin film): 1714, 1732 $\mathrm{cm}^{-1}$; ${ }^{1} \mathrm{H}$ NMR $\left(400 \mathrm{MHz}, \mathrm{CDCl}_{3}\right.$, TMS): $\delta_{\mathrm{H}} 0.84(\mathrm{t}, J 7.3 \mathrm{~Hz}, 3 \mathrm{H}), 1.21-1.33(\mathrm{~m}, 2 \mathrm{H}), 1.43-1.52$ $(\mathrm{m}, 2 \mathrm{H}), 1.70(\mathrm{~s}, 3 \mathrm{H}), 1.82(\mathrm{~s}, 3 \mathrm{H}), 2.63-2.78(\mathrm{~m}, 2 \mathrm{H}), 7.05-7.73(\mathrm{~m}, 15 \mathrm{H}) ;{ }^{13} \mathrm{C} \mathrm{NMR}(100 \mathrm{MHz}$, $\left.\mathrm{CDCl}_{3}\right): \delta_{\mathrm{C}} 13.9,21.0,22.4,23.9,26.8,39.0,61.7,126.9,126.9,127.4,128.1,128.1,128.2$, 128.3, 129.3, 129.6, 130.3, 133.0, 141.1, 141.2, 143.6, 164.8, 208.0; MS (EI 70 eV): m/z 341, 237, 220, 205, 105; $(\mathrm{M}+\mathrm{H})^{+}$HRMS $m / z$ Calcd for $\left(\mathrm{C}_{29} \mathrm{H}_{31} \mathrm{O}_{3}\right)^{+}: 427.2268$; found: 427.2270.

(Z)-4-Methyl-5-oxo-2,4-di-p-tolylnon-2-en-3-ylpropionate (2g). Clear viscous oil, yield 41\%, $28 \mathrm{mg}$, dr $>95: 5$ as determined by ${ }^{1} \mathrm{H}$ NMR and GC-MS analysis; IR $\left(v_{\max }, \mathrm{cm}^{-1}\right.$, thin film): 1712, $1751 \mathrm{~cm}^{-1} ;{ }^{1} \mathrm{H} \mathrm{NMR}\left(400 \mathrm{MHz}, \mathrm{CDCl}_{3}, \mathrm{TMS}\right): \delta_{\mathrm{H}} 0.77(\mathrm{t}, J 7.6 \mathrm{~Hz}, 3 \mathrm{H}), 0.86(\mathrm{t}, J 7.3 \mathrm{~Hz}$, $3 \mathrm{H}), 1.23-1.30(\mathrm{~m}, 2 \mathrm{H}), 1.54-1.56(\mathrm{~m}, 2 \mathrm{H}), 1.62(\mathrm{~s}, 3 \mathrm{H}), 1.74(\mathrm{~s}, 3 \mathrm{H}), 1.86-1.93(\mathrm{~m}, 2 \mathrm{H}), 2.32(\mathrm{~s}$, $3 \mathrm{H}), 2.34(\mathrm{~s}, 3 \mathrm{H}), 2.52-2.70(\mathrm{~m}, 2 \mathrm{H}), 7.07-7.44(\mathrm{~m}, 8 \mathrm{H}) ;{ }^{13} \mathrm{C} \mathrm{NMR}\left(100 \mathrm{MHz}, \mathrm{CDCl}_{3}\right): \delta_{\mathrm{C}} 8.7$, 13.9, 20.9, 21.0, 21.1, 22.4, 23.4, 26.9, 27.1, 39.0, 61.1, 127.4, 128.0, 128.7, 128.9, 129.4, 136.4, 136.5, 138.0, 138.5, 143.7, 172.4, 208.6; MS (EI $70 \mathrm{eV}): \mathrm{m} / z$ 350, 321, 265, 248, 233; (M + H) HRMS m/z Calcd for $\left(\mathrm{C}_{27} \mathrm{H}_{35} \mathrm{O}_{3}\right)^{+}:$407.2581; found: 407.2584 .

\section{Assignment of olefin stereochemistry of enol esters 2}

The major isomer of the enol ester 2a was determined to be the $Z$-isomer on the basis of NOESY experiments, which demonstrated an NOE between the two Me groups of the enol ester (see Supplementary Materials). The major isomer of all other enol esters was assigned to be the Zisomer by analogy.

\section{Acknowledgements}

We thank the National Science Foundation (Grant Nos. CHE-0911483 and CHE-1213638 to N.J.K., CHE-0821487 for NMR facilities at Oakland University, and CHE-1048719 for LC-MS facilities at Oakland University).

\section{References}

1. Hansen, D. W. Jr.; Pappo, R.; Garland, R. B. J. Org. Chem. 1988, 53, 4244-4253. http://dx.doi.org/10.1021/jo00253a016

2. Duan, H.; Sun, X.; Liao, W.; Petersen, J. L.; Shi, X. Org. Lett. 2008, 10, 4113-4116. http://dx.doi.org/10.1021/o1801656y

PMid:18722449

3. Tang, W.; Liu, D.; Zhang, X. Org. Lett. 2003, 5, 205-207. 
http://dx.doi.org/10.1021/o10272592

PMid:12529141

4. Smith, M. B.; March, J. In March's Advanced Organic Chemistry: Reactions, Mechanisms, and Structure, 5th Edn.; Wiley \& Sons: NY, 2001; Chapter 10-117, p 569.

5. Lim, D.; Fang, F.; Zhou, G.; Coltart, D. M. Org. Lett. 2007, 9, 4139-4142.

http://dx.doi.org/10.1021/o1701599v

PMid: 17877360

6. Wasserman, H. H.; Keller, L. S. Tetrahedron Lett. 1974, 15, 4355-4358.

http://dx.doi.org/10.1016/S0040-4039(01)92162-8

7. Mukaiyama, T.; Murakami, M.; Yamaguchi, M. Chem. Lett. 1980, 9, 529-532.

http://dx.doi.org/10.1246/cl.1980.529

8. Huang, F.; Quach, T. D.; Batey, R. A. Org. Lett. 2013, 15, 3150-3153.

http://dx.doi.org/10.1021/o14013712

PMid:23734856

9. Mamone, P.; Grünberg, M. F.; Fromm, A.; Khan, B. A.; Gooßen, L. J. Org. Lett. 2012, 14, 3716-3719.

http://dx.doi.org/10.1021/o1301563g

PMid:22747236

10. DeBergh, J. R.; Spivey, K. M.; Ready, J. M. J. Am. Chem. Soc. 2008, 130, 7828-7829.

http://dx.doi.org/10.1021/ja803480b

PMid:18517202 PMCid:PMC2668979

11. Okamoto, N.; Miwa, Y.; Minami, H.; Takeda, K.; Yanada, R. J. Org. Chem. 2011, 76, 91339138.

http://dx.doi.org/10.1021/jo201609r

PMid:21950658

12. Ibrahim, A. A.; Harzmann, G. D.; Kerrigan, N. J. J. Org. Chem. 2009, 74, 1777-1780.

http://dx.doi.org/10.1021/jo8024785

PMid:19152318

13. Wei, P.-H.; Ibrahim, A. A.; Mondal, M.; Nalla, D.; Harzmann, G. D.; Tedeschi, F. A.; Wheeler, K. A.; Kerrigan, N. J. Tetrahedron Lett. 2010, 51, 6690-6694.

http://dx.doi.org/10.1016/j.tetlet.2010.10.026

14. Lv, H.; Zhang, Y.- R.; Huang, X.-L.; Ye, S. Adv. Synth. Catal. 2008, 350, 2715-2718. http://dx.doi.org/10.1002/adsc.200800532

15. Ibrahim, A. A.; Wei, P.-H.; Harzmann, G. D.; Kerrigan, N. J. J. Org. Chem. 2010, 75, 79017904.

http://dx.doi.org/10.1021/jo101867m

PMid:21033697

16. Ibrahim, A. A.; Smith, S. M.; Henson, S.; Kerrigan, N. J. Tetrahedron Lett. 2009, 50, 69196922.

http://dx.doi.org/10.1016/j.tetlet.2009.09.158 
17. Yang, D.; Zhang, C. J. Org. Chem. 2001, 66, 4814-4818.

http://dx.doi.org/10.1021/jo010122p

18. Rasmussen, K; Calligaro, D. O.; Czachura, J. F.; Dreshfield-Ahmad, L. J.; Evans, D. C.; Hemrick-Luecke, S. K.; Kallman, M. J.; Kendrick, W. T.; Leander, J. D.; Nelson, D. L.; Overshiner, C. D.; Wainscott, D. B.; Wolff, M. C.; Wong, D. T.; Branchek, T. A.; Zgombick, J. M.; Xu, Y.- C. J. Pharmacol. Exp. Ther. 2000, 294, 688-700.

19. Pearson, R. G.; Songstad, J. J. Am. Chem. Soc. 1967, 89, 1827-1836. http://dx.doi.org/10.1021/ja00984a014

20. Armarego, W. L. F.; Perrin, D. D. In Purification of Laboratory Chemicals, 4th Edn.; Butterworth Heinemann, 2002.

21. Kamienski, C. W.; Esmay, D. L. J. Org. Chem. 1960, 25, 1807-1808. http://dx.doi.org/10.1021/jo01080a035

22. Tyler, L. J.; Sommer, L. H.; Whitmore, F. C. J. Am. Chem. Soc. 1948, 70, 2876-2878. http://dx.doi.org/10.1021/ja01189a012 